\title{
COVID-19 pandemic impacts to Dentistry
}

\section{Impactos da pandemia causada pela covid-19 na Odontologia}

\author{
Matheus Simões MEDEIROS1 iD http://orcid.org/0000-0003-2822-0796 \\ Haniel Laurentino Ferreira dos SANTOS ${ }^{1}$ iD http://orcid.org/0000-0002-8341-7172 \\ Jaqueline Oliveira BARRETO2 (iD http://orcid.org/0000-0001-8172-0293 \\ Julliana Cariry Palhano FREIRE ${ }^{3}$ iD http://orcid.org/0000-0001-7652-102X \\ Eduardo DIAS-RIBEIRO4 iD http://orcid.org/0000-0002-6321-4159
}

\begin{abstract}
Objective: To achieve a literature review on the impacts of COVID-19 on dentistry. Methods: Analysis of scientific articles contained in the LILACS and PubMed platforms that fulfill the informative purpose of the research. Results: The production of aerosols during dental procedures could be highlighted as the most dangerous agent, the literature recommends restricting the type of service only to emergencies and reducing the use of rotating instruments or cough-inducing equipaments. New protective measures must be taken, such as the type of PPE used and the frequency of asepsis of the workplace, since any surface that has been exposed to oral or pharyngeal secretions may contain a load of viral particles, an online triage is also recommended before any assistance. Due to the easy spreading of this disease and the possibility of asymptomatic patients, the current best measure is avoiding the execution of procediments. Conclusion: COVID-19 will be a milestone for the current generations of health professionals, it could also be an advance for use distance technologies and integration of new biosafety techniques.
\end{abstract}

Indexing terms: Coronavirus infections. Dentistry. Pandemics.

\section{RESUMO}

Objetivo: Realizar uma revisão de literatura sobre os impactos da COVID-19 na Odontologia. Métodos: Análise de artigos científicos contidos nas plataformas LILACS e PubMed que cumprissem o intuito informativo da pesquisa. Resultados: Pôde-se destacar como agente de maior periculosidade a produção de aerossóis durante os procedimentos odontológicos, a literatura recomenda restringir o tipo de atendimento apenas a emergências e reduzir o uso de instrumentos rotatórios ou que induzam tosse. Novas medidas de proteção devem ser tomadas, como tipo de EPI utilizado e frequência de assepsia do local de trabalho, pois qualquer superfície que fora exposta a secreções orais ou faríngeas pode conter uma carga de partículas virais, também se recomenda uma pré-triagem não presencial antes de qualquer atendimento. Pela facilidade de disseminação da doença e a possibilidade existência de pacientes assintomáticos, a melhor medida ainda é evitar a realização de atendimentos Conclusão: A COVID-19 será um marco para as atuais gerações de profissionais da saúde, podendo ser um avanço para utilização de tecnologias a distância e integralização de novas técnicas de biossegurança.

Termos de indexação: Infecções por Coronavirus. Odontologia. Pandemia.

\section{$\boldsymbol{V} \nabla \boldsymbol{V}$}

1 Universidade Federal da Paraíba, Departamento de Odontologia. Castelo Branco, 58051-900, João Pessoa, PB, Brasil. Correspondência para / Correspondence to: MS MEDEIROS. E-mail: <matheus_simoes2012@live.com>.

2 Universidade Federal de Campina Grande, Departamento de Odontologia. João Pessoa, PB, Brasil.

3 Universidade Estadual da Paraíba, Departamento de Odontologia. Campina Grande, PB, Brasil.

${ }^{4}$ Universidade Federal da Paraíba, Departamento de Cirurgia e Traumatologia Bucomaxilofacial. João Pessoa, PB, Brasil.

$\checkmark v \nabla$

How to cite this article

Medeiros MS, Santos HLF, Barreto JO, Freire JCP, Dias-Ribeiro E. COVID-19 pandemic impacts to Dentistry. RGO, Rev Gaúch Odontol. 2020;68:e20200021. http://dx.doi.org/10.1590/1981-863720200002020200079 


\section{INTRODUCTION}

Coronavirus is a virus family that cause respiratory infections [1]. In December 2019, an outbreak of pneumonia caused by a new strain of Coronavirus started in the city of Wuhan, Hubei province - China, and quickly spread [2]. Most of primary cases were linked to seafood merchants, this suggests the pathogen was transmitted from animals to humans, its first identification was in 2019. The virus may have come from regional bats, having as host the Pangolin, an anteater species [3].

The current expansion of the new coronavirus (COVID-19) quickly led to a health crisis that spread throughout world. Main symptoms are predicted by Severe Acute Respiratory Syndrome, first identified in 2002 as SARS-CoV and in the Middle East

Respiratory Syndrome, identified in 2012 as MERS-CoV [4]. As health professionals, be aware of the biological and social effects of COVID-19 [1] is extremely relevant for dentists.

These professionals must be prepared to deal with its disease and identify the new coronavirus [4]. The Occupational Health and Safety Administration (OSHA) classified dentists as professionals at very high-risk of infection [5]. They can be powerful means of spreading. These risks are attributed to the nature of dental procedures that come into direct contact with the areas of greatest virus proliferation (nasopharynx) and the distance between the professional and patient [4].

The pandemic reminds dentists and other health professionals the duty of being always on the lookout for protection from infectious diseases [6]. Many symptoms can be treated and professional assistance is able to make them less dangerous at all [2]. According to the Chinese health service, the first 138 cases treated at the Wuhan Hospital, 40 of them (29\% of cases) were health professionals [7].
This study aimed to conduct a literature review of COVID-19 impacts on dentistry, as well as raising awareness about this pandemic.

\section{METHODS}

Literature review of studies published by PubMed (National Library of Medicine; https://www.ncbi.nlm.nih. gov/pubmed/) and LILACS (Latin American and Caribbean Health Sciences Literature; https://lilacs.bvsalud.org/) which databases was conducted from April to May 2020. The strategies used to locate the articles were guided by the question and inclusion criteria previously established to maintain consistency searching the articles and avoid possible bias. The keywords were used according to Medical Subject Headings (MESH; https://www.ncbi.nlm. nih.gov/mesh) and Health Sciences Descriptors (Decs; http: //decs.bvs.br/), comprehensive controlled vocabulary for the purpose of indexing journal articles and books in the life sciences. The research strategies are shown in chart 1.

Inclusion criteria were articles published in English, which show impacts of COVID-19 on dentistry. Exclusion criteria were articles that did not have their abstracts available in the selected databases, during period covered by this research.

197 articles were initially found on the PubMed platform. After analyzing titles, 30 articles were classified as relevant to the research and after its full reading, only 12 were included in this review.

On LILACS platform were initially found 20 articles, which 5 comprehend the purpose of this review and after its full reading, only one proved to be relevant to the current research.

Therefore, 13 articles were included in this review.

\section{RESULTS}

New coronavirus has gained an immeasurable worldwide prominence in the health field. Impacts of

Chart 1. Search strategy and key-words.

\begin{tabular}{|l|l|}
\hline Database / Search terms \\
\hline PubMed & Lilacs \\
\hline Search filters & $\begin{array}{l}\text { Publication data from last year. } \\
\text { Covid-19 [Text word] or Coronavirus [Text word] and Dentistry [Text word] }\end{array}$ \\
\hline $\begin{array}{l}\text { Publication data from last year. } \\
\text { ((Coronavirus) OR COVID-19) AND Dentistry }\end{array}$ & \\
\hline
\end{tabular}


the pandemic brought to light several outstanding points related to biosafety, the role of professionals and the economic and social aspects linked to the rapid proliferation of the disease [1-4].

Ather et al. [4] defines scientific point of view of the disease. As mentioned by the author, in academic environment an outbreak of a respiratory infection was not as unexpected as it is widespread, other infections like SARS-CoV and MERS were favored as potential pandemics in 2004 and 2012.

While SARS-CoV depended on closer contact with the infected person, COVID-19 can be transmitted by even larger areas due its airborne particles generated by coughing or sneezing [4]. The author also emphasizes the dental health professional as an agent for the spread of the disease, because its high risk of infection and the high number of people in contact with it, as well as the dental office, which can, for a long time, accumulate aerosols from contaminated patients generated by procedures in the oral cavity [4].

Sabino et al. [6] claim that the new coronavirus pandemic reminds the role of the health professional in maintaining a strict biosafety control.

Khader et al. [8] conducted a survey with dentists in Jordan about their perception of the new coronavirus. Through an online questionnaire, $74 \%$ of dentists believe that social distancing between patients and use of masks is necessary in the waiting room. $82 \%$ of the dentists agree to use PPE in the entire work team of the dental office.

Measures such as the use of a hand sanitizer frequently, increased cleaning routine of surfaces and reinforced use of PPE, was consensus in at least $92.9 \%$ of respondents [8].

In the study, the perception of seriousness of the disease by dentists was also questioned, where only $17.7 \%$ classified it as very dangerous, $71.7 \%$ as moderate and $9.5 \%$ as not dangerous. $49.5 \%$ of the dentists stated that they would treat a patient even if he was coughing or sneezing and $32.3 \%$ would allow the work team to have contact with patients who had any flu symptoms [8].

For Napimoga and Freitas [7], dental profession had gained attention during the pandemic by health organizations due to intrinsic nature of its procedures. The new coronavirus has great affinity for nasopharyngeal cells, so saliva has a high viral load. Any clinical performance by the dentist might lead to an invisible spread of the virus through the air.
As reviewed by this same author, $29 \%$ of the cases registered at the Wuhan hospital, the first epicenter of the disease, were health professionals. The rapid detection and treatment of these has made possible a greater containment of COVID-19, since clinical studies with IgM and IgG immunoglobulins have shown that cured patients do not acquire the infection again [7].

Pereira et al. [1] deepens the biological knowledge related to COVID-19. The author emphasizes the importance that dentists must give to the social and biological aspects of this disease. Like a virus, this pathogen has the ability to suppress the patient's immune system, especially interferon factors.

Pereira et al. [1] also focuses to the existence of asymptomatic patients who can be major vectors if they have contact with other patients in the waiting room, for example. His study proposes not to perform intraoral radiographs during this period, as it might induce coughing in the patient, generating strong air contamination.

Preclinical screening done by the dentist can be essential in the current times, such method is outstanding in the Campos et a.'s work [2], the author recommends that the dentist asks a series of questions for the patient, thus being able to classify them as possibly infected and if so, reschedule the appointment. In the case of symptomatic patients, looking for medical assistance is recommended. In case of emergency care, stricter biosafety measures must be taken, such as the use of HEPA filters and negative pressure isolation [2].

Meng et al. [9], reinforce the idea of diagnosis based on a series of questions asked to the patient, so that assessment of patients begins before the office in a pre-screening. Authors recommend that clinic's entire work team should be also monitored, especially their body temperature.

Before performing any procedure in the oral cavity, the use of antimicrobial mouthwashes can reduce the number of microbes in the oral cavity [9]. The chinese authors recommend that emergency treatments should be treated only if they are really urgent.

Izzetti et al. [10] review (2020) analyzes the possible transmission of the virus in Italy caused by the dental practice. The author reports that in the sample analyzed, 1,600 patients who answered online consultations, only 19 had been diagnosed with COVID-19. The author recommends that only dental emergencies such as pulpotomy and extractions be performed, however, if the 
patient is from a risk group or has risk factors, it is highly recommended that no procedure must be performed.

Its statement new biosafety practices, such as encouraging the patient to enter the dental office with only the clothes on, leaving coats, cell phones and bags in the waiting room, as well as the use of $0.2 \%$ to $1 \%$ Povidone, $0.05 \%$ to $0.1 \%$ cetylpyridine chloride or $1 \%$ hydrogen peroxide as mouthwash before procedures [10].

Ge et al. [3] restates the need to perform the patient's oral asepsis, ever since particles smaller than $5 \mu \mathrm{m}$ can contain a significant viral load. The author cites studies done in 2004, whose observed that SARS-CoV viral RNA was found in very high amounts in saliva, from $6.38 \times 108$ to $7.08 \times 103$ copies per milliliter. Fortunately, there are no reported cases of transmission of COVID-19 by dental instruments.

Bouguezzi et al. [11] redefines essential protocols for the dentist's safety in each area of expertise. In all of them, the use of rotary instruments, periodontal hand instruments, odontological ultrasound and prosthetic molds are not recommended, as they can induce coughing. If necessary, it is up to the dentist to prefer atraumatic restorative techniques.

Sandle [12] resumes the Public Health England (PHE) classification of COVID-19 as an airborne high incidence infectious disease to alert dental health professionals that any and all procedures are likely to spread the disease. In his article, the author reports that viral particles can remain for up to 9 days on inanimate surfaces such as metal, glass or plastic which are not properly sanitized.

As first epicenter, Wuhan quickly had a lockdown to contain the spread of the disease, which had widely positive effects as seen in Lau et al. [13]. Hubei province was put under lockdown approximately three weeks after the coronavirus outbreak. In Wuhan, the imposed lockdown resulted in restrictions for inbound or outbound travel, ensuring strict adherence to home quarantine.

While the dental professional may still work, the student had his face-to-face activities interrupted all over the world. lyer et al. [5] highlighted the challenge of keeping dental schools active during the pandemic. This teaching modality (distance learning) is flexible enough to deviate from the standard pragmatic content. In addition to no experience with the patient, the student will not have access to the laboratories.

These authors [5] researched 67 universities in the United States and observed that most of them had their face-to-face activities stopped, except for emergencies such as pulpitis, bacterial infections with extra-oral exposure, severe pain, uncontrolled bleeding, trauma or avulsion [5]. The students were assigned to carry out online activities, however, the teaching methods are still not promising, as the author quotes, teachers have not yet had time to plan an effective distance learning strategy. Iver et al. [5] considers the current situation as an opportunity to universities develop and invest in distance learning.

\section{DISCUSSION}

Today, 07/05/20 at 21:45, the confirmed cases and the mortality rate, respectively, of COVID-19 in the world is 3,836,215 infected and 7,4\%, in Brazil, there are 135,773 infected and $6,7 \%$ [14], while H1N1, a recurrent flu in Brazil, has a lethality rate of less than $1 \%$ [15].

The dentist was classified by several entities as an extremely high-risk agent and few professions are at similar risk $[4,5,7,12]$. The proximity to the oral cavity and the possible production of aerosols during dental procedures are strong disseminators of viral particles present in saliva [3].

As seen in the previous by Khader et al. [9], the dentist perception can still be vague as to the real problem. The use of a strict service protocol and consultation restrictions are clearly necessary for the dentistry practice in times of coronavirus. In addition to the standard biosafety protocols, new measures must be taken $[1,2,9,10]$, as seen in the scheme below.

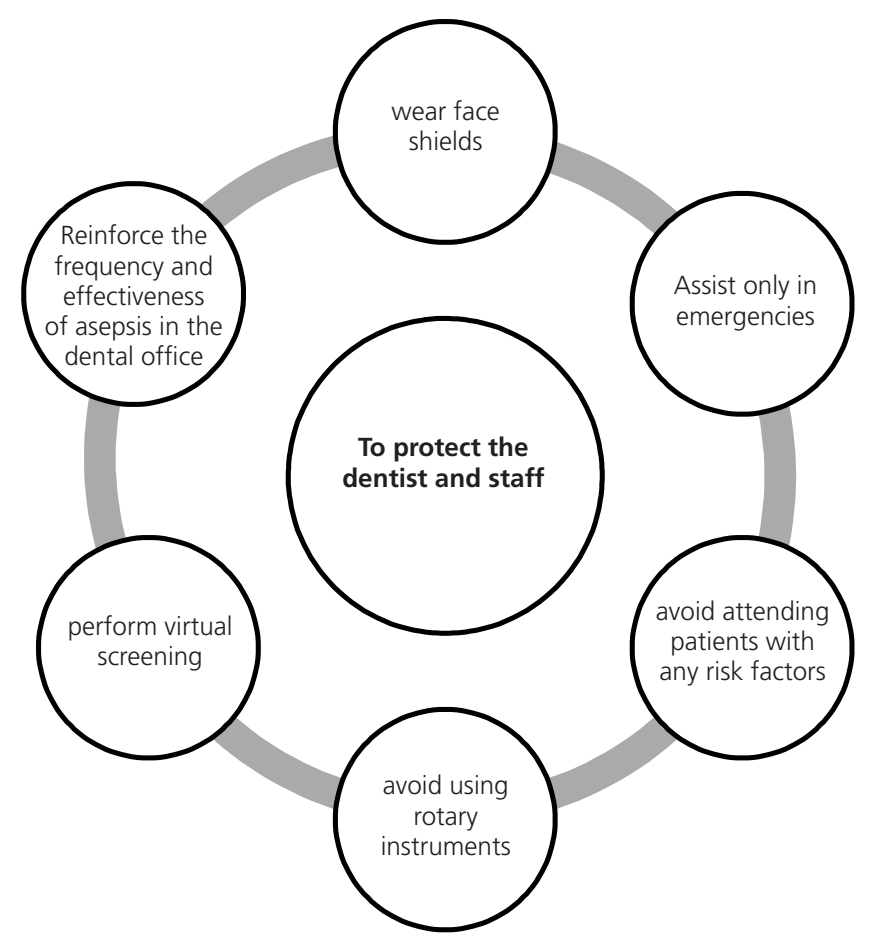


Emphasized in most authors, the use of mouthwashes was widely recommended $[10,11]$, the technique is effective in reducing viral load in the mouth for a period of time [16]. In all studies related to dental care $[3-6,10,11]$, it is recommended to perform procedures only in urgent cases. Pre-screening performed by telephone or internet is a great ally of the dentist [9], however, there are asymptomatic patients and the performance of only one procedure in this patient can generate aerosols and leave the entire area contaminated for up to 9 days if there is no rigid asepsis [1,2].

Social distancing is still the best strategy to avoid contamination. Even with all possible care, the dentist and the patient are frequently at risk $[3,6,9]$. Wuhan's example in comparison with Italy was of great importance to scientific community, the city underwent a rapid lockdown that generated a significant containment of cases in the country and infection flattening of curve, because of the time doubled for the same number of infected in Italy is a major milestone [13].

The fight against COVID-19 is above all a fight against time. The dispute for hospital beds does not need to exist if there is an infection control of people simultaneously. Over the months it is likely that more effective treatments, medications and even vaccines will appear.

Most authors agree on the adoption of new protection measures $[2-6,8]$, pre-screening $[1,2,4,5,9]$ and performing procedures only in emergencies $[3-6,10,11]$, however, in a matter of days the world scene changes, all these articles were published in the pandemic's first months first months. Due the current spread of the disease and the high rate of deaths worldwide, the best measure is interrupting all dental act, except for the awareness work done by dentists, who are, above all, health professionals.

As mentioned by lyer et al. [5], future generations of dentists will have greater interaction with teleodontology. The pandemic may have stressed the administration of dental schools about the importance of technology and even forced them to see it as a method of biosafety.

\section{CONCLUSION}

The new coronavirus has brought into view a world never seen by current generations of healthcare professionals. The dentist was suddenly outstanding due to intrinsic nature of his performance. Biosafety has become visually transformed into measures that save lives, in addition, it has returned attention to the protection of the work team and other patients, not just the dentist. COVID-19's impacts on dentistry may be promising after all, for the time being the best strategy is to abstain from any unnecessary social contact.

\section{Collaborators}

MS Medeiros, as the main responsible for the idealization. HLF Santos, formal analysis, investigation, resources, validation. JO Barreto, conceptualization, formal analysis, investigation, methodology, supervision, validation and visualization. JCP Freire, project administration, supervision, validation and visualization. E Dias-Ribeiro conceptualization, formal analysis, methodology, supervision, validation and visualization.

\section{Acknowledgement}

Foremost, I would like to express my sincere gratitude to Mariana de Andrade who helped translating this article.

\section{REFERENCES}

1. Pereira LJ, Pereira CV, Murata RM, Pardi V, Pereira-Dourado SM. Biological and social aspects of Coronavirus Disease 2019 (COVID-19) related to oral health. Braz Oral Res. 2020;34(41):1-11. https://doi.org/10.1590/1807-3107bor-2020.vol34.0041

2. de Campos Tuñas IT, da Silva ET, Santiago SB, Maia KD, SilvaJúnior GO. Doença pelo Coronavírus 2019 (COVID-19): Uma abordagem preventiva para Odontologia. Rev Bras Odontol. 2020;77:1-7. http://dx.doi.org/10.18363/rbo.v77.2020.e1776

3. Ge ZY, Yang LM, Xia JJ, Fu XH, Zhang YZ. Possible aerosol transmission of COVID-19 and special precautions in dentistry. J Zhejiang Univ Sci B. 2020;16:1-8. https://doi.org/10.1631/ jzus.B2010010

4. Ather A, Patel B, Ruparel NB, Diogenes A, Hargreaves KM. Coronavirus Disease 19 (COVID-19): implications for clinical dental care. J Endod. 2020;44(5):584-595. https://doi. org/10.1016/j.joen.2020.03.008

5. Iyer P, Aziz K, Ojcius DM. Impact of COVID-19 on dental education in the United States. J Dental Educ. 2020;84(4):1-5. https://doi.org/10.1002/jdd. 12163

6. Sabino-Silva R, Jardim AC, Siqueira WL. Coronavirus COVID-19 impacts to dentistry and potential salivary diagnosis. Clinical Oral Investig. 2020;24(1):1619-1621. https://doi.org/10.1007/s007 84-020-03248-x

7. Napimoga MH, Freitas AR. Dentistry vs Severe Acute Respiratory Syndrome Coronavirus 2: How to face this 
enemy. RGO, Rev Gauch Odontol. 2020;68(1):1-2. https:// doi.org/10.1590/1981-86720200001120200034

8. Khader Y, Al Nsour M, Al-Batayneh OB, Saadeh R, Bashier H, Alfaqih $M$, et al. Dentists' awareness, perception, and attitude regarding covid-19 and infection control: cross-sectional study among jordanian dentists. JMIR Public Health Surveill. 2020;6(2):e18798. https://doi.org/10.2196/18798

9. Meng L, Hua F, Bian Z. Coronavirus disease 2019 (COVID-19): emerging and future challenges for dental and oral medicine. J Dental Res. 2020;99(5):481-487. https://doi.org/10.1177/00 22034520914246

10. Izzetti R, Nisi M, Gabriele M, Graziani F. COVID-19 Transmission in dental practice: brief review of preventive measures in Italy. J Dental Res. 2020;99(5):1-9. https://doi. org/10.1177/0022034520920580

11. Bouguezzi A, Cherni I, Sioud S, Hentati H, Selmi J. COVID-19: special precautions in Dentistry. OAJBS. 2020;2(1):283-284. https://doi.org/10.38125/OAJBS.000164

12. Sandle Tim. COVID-19 and dental practice. Dental Nurs. 2020;16(4):1-2. https://doi.org/10.12968/denn.2020.16.4.194
13. Lau H, Khosrawipour $V$, Kocbach P, Mikolajczyk A, Schubert J, Bania J, Khosrawipour T. The positive impact of lockdown in Wuhan on containing the COVID-19 outbreak in China. J Travel Med. 2020;27(2):1-14. https://doi.org/10.1093/jtm/ taaa037

14. Rastreador do COVID-19 - Bing [Internet]. Bing. 2020 May [acessado 2020 Maio 7]. Avaliable in: https://www.bing.com/ covid/

15. 2009 H1N1 Pandemic - Center for Disease Control and Prevention [Internet]. Center for Disease Control and Prevention. 2019 June [acessado 2020 Maio 7]. Avaliable in: https://www.cdc.gov/flu/ pandemic-resources/2009-h1n1-pandemic.html

16. Howe M. Mouthwash; can it reduce levels of Covid-19 in the mouth? - National Elf Service [Internet]. National Elf Service. 2020 [acessado 2020 Maio 8]. Avaliable in: https://www. nationalelfservice.net/dentistry/oral-medicine-and-pathology/ mouthwash-reduce-levels-covid-19-mouth/

Received on: 21/5/2020 Final version resubmitted on: 27/5/2020

Approved on: 24/6/2020 